\title{
ANALISA FAKTOR-FAKTOR YANG MEMPENGARUHI PEMILIHAN LOKASI TERHADAP TINGKAT PENJUALAN USAHA JASA MIKRO DI KABUPATEN LAMONGAN
}

\author{
*( Ali fathoni \\ Prodi Manajemen, Fakultas Ekonomi, Universitas Islam Lamongan \\ $\mathrm{Jl}$. Veteran No.53A Lamongan \\ Telp. ( 0322 ) 324706, Faks. ( 0322 ) 324706 \\ Email:jpim.unisla@gmail.com
}

\section{ABSTRAK}

Penelitian ini merupakan jenis penelitian kuantitatif yang bertujuan untuk mencari jawaban dari pertanyaan "apakah faktor kedekatan dengan infrastruktur, lingkungan bisnis, biaya lokasi berpengaruh secara parsial dan simultan terhadap tingkat penjualan usaha jasa skala mikro dan kecil di Desa Blimbing Kec. Paciran Kab. Lamongan?". "dan manakah variabel yang paling dominan terhadap tingkat penjualan usaha jasa skala mikro dan kecil di Desa Blimbing Kec. Paciran Kab. Lamongan?". Penelitian ini menggunakan metode analisa data uji validitas dan uji reliabilitas, uji asumsi klasik, analisis regresi berganda, dan uji goodness of fit. Hasil penelitiannya yaitu untuk variabel infrastruktur tidak berpengaruh secara parsial sedangkan variabel lingkungan bisnis dan biaya lokasi berpengaruh secara parsial. Dan untuk semua variabel memiliki pengaruh secara simultan. Dan variabel yang paling dominan dimiliki oleh variabel lingkungan bisnis. Dari hasil analisa tersebut dapat disimpulkan bahwa infrastruktur tidak berpengaruh signifikan terhadap tingkat penjualan, sedangkan lingkungan bisnis dan biaya lokasi berpengaruh signifikan terhadap tingkat penjualan. Berdasarkan kesimpulan diajukan saran kepada pengusaha agar lebih cermat dalam menentukan pemilihan lokasi guna meningkatkan tingkat penjualan yang diharapkan semua pengusaha.

Kata Kunci: Pemilihan lokasi, Tingkat Penjualan, Usaha jasa mikro

\section{PENDAHULUAN}

Banyaknya perusahaan yang bergerak dalam bisnis saat ini akan menimbulkan persaingan yang semakin ketat. Situasi yang seperti ini menuntut setiap perusahaan untuk lebih seksama mengarahkan perhatian pada banyak faktor untuk menentukan keberhasilannya.

Salah satunya adalah menentukan lokasi tempat untuk bisnis. Lokasi adalah letak atau tempat yang digunakan pengusaha pada daerah yang strategis sehingga dapat memaksimalkan laba. Lokasi pemasaran yang nyaman, aman, bersih, ramai, dan mudah di jangkau merupakan beberapa kriteria lokasi yang diminati oleh banyak konsumen. Lokasi pemasaran adalah suatu wilayah atau tempat dimana perusahaan dapat menjalankan atau melaksanakan kegiatan pemasarannya kepada masyarakat. Jadi memilih 
lokasi berdagang merupakan keputusan penting yang harus membujuk pelanggan untuk datang ke tempat bisnis dalam memenuhi kebutuhan, karena pemilihan lokasi mempunyai fungsi yang strategis dalam menentukan tercapainya tujuan badan usaha.

Pemilihan lokasi suatu perusahaan akan mempengaruhi resiko dan keuntungan perusahaan tersebut secara keseluruhan, mengingat lokasi sangat mempengaruhi biaya tetap maupun biaya variabel, baik dalam jangka menengah maupun jangka panjang. Sebagai contoh, biaya transportasi saja bisa mencapai $25 \%$ harga jual produk (tergantung kepada produk dan tipe produksi atau jasa yang diberikan). Hal ini berarti bahwa seperempat total pendapatan perusahaan mungkin dibutuhkan hanya untuk menutup biaya pengangkutan bahan mentah yang masuk dan produk jasa yang keluar dari perusahaan.

Menurut departemen tenaga kerja (Depnaker) usaha mikro adalah usaha yang memilki kurang dari lima orang tenaga kerja.Usaha mikro merupakan kegiatan usaha yang dapat memperluas lapangan pekerjaan serta memberikan pelayanan ekonomi secara luas kepada masyarakat dan dapat berperan dalam proses pemerataan dan peningkatan pendapatan masyarakat, mendorong pertumbuhan ekonomi, serta berperan mewujudkan stabilitas nasional. Selain itu usaha mikro adalah salah satu pilar utama ekonomi nasional yang mendapatkan kesempatan utama, dukungan, perlindungan serta pengembangan yang secara luas sebagai wujud pihak yang tegas kepada kelompok usaha ekonomi rakyat, tanpa harus mengabaikan peranan usaha besar dan badan usaha milik pemerintah.

Keberadaan Desa Blimbing merupakan magnet bagi seorang pengusaha untuk mendirikan usaha jasa disekitarnya. Hal ini tidak terlepas dari terciptanya pasar yang sangat potensial dari keberadaan Desa Blimbing itu sendiri. Banyaknya masyarakat di Desa Blimbing merupakan pasar yang sangat potensial untuk dijadikan lahan bisnis. Hal inilah yang menyebabkan fenomena menjamurnya usaha jasa yang didirikan di Desa Blimbing. Bagi usaha jasa, lokasi yang strategis seringkali lebih penting dari pada faktor-faktor yang lain. Hal ini berarti bahwa pengusaha rela membayar biaya yang lebih besar untuk pemilihan lokasi dengan mengharapkan pendapatan besar sebagai akibat pemilihan lokasi yang tepat. Hal ini juga terjadi pada usaha jasa yang berdiri di sekitar Desa Blimbing. Mereka rela membayar mahal untuk membuka usaha di lokasi ini dengan mengharapkan pendapatan yang besar mengingat adanya pasar yang potensial akibat adanya penduduk yang sangat padat di sekitar Desa Blimbing. Disamping faktor biaya, faktor kedekatan dengan infrastruktur dan kedekatan dengan lingkungan bisnis merupakan hal-hal yang diperhatikan pengusaha sebelum mendirikan usaha di sekitar Desa Blimbing. 


\section{LANDASAN TEORI}

Lokasi adalah letak atau toko pengecer pada daerah yang strategis sehingga dapat memaksimumkan laba (Basu Swasta dan Irawan dalam Rusdiana, 2014:248). Sedangkan pengertian lokasi menurut (Kasmir dalam Muhammad Shobakh, 2013:11) yaitu tempat melayani konsumen, dapat pula diartikan sebagai tempat untuk memajang barang-barang dagangannya.

Dengan demikian yang dimaksud dengan lokasi adalah tempat menjalankan aktivitas yang melayani konsumen, aktivitas produksi, aktivitas penyimpanan, ataupun untuk mengendalikan kegiatan perusahaan secara keseluruhan.

Menurut (Suliyanto, 2010:134) Lokasi bisnis adalah lokasi dimana bisnis anda akan dijalankan. Faktorfaktor utama dalam pemilihan lokasi adalah:

1) Ketersediaan Bahan Mentah;

2) Letak pasar yang dituju;

3) Ketersediaan sumber energi, air, dan sarana komunikasi;

4) Ketersediaan tenaga kerja;

5) Ketersediaan sarana transportasi. Menurut (Rusdiana, 2014:266267), langkah-langkah dalam menentukan lokasi usaha adalah:

1) Merumuskan sasaran pemilihan tempat kedudukan perusahaan;

2) Merumuskan batas atau kendala;

3) Merumuskan Norma-Norma Keputusan;

4) Menghubungkan Norma-Norma Keputusan dengan Sasaran Pemilihan Lokasi;
5) Membentuk

Model-Model Pengambilan Keputusan;

6) Menentukan Lokasi Terbaik. Menurut definisi dari Asosiasi Pemasaran Amerika (The American Marketing Association) dalam (Susatyo Herlambang 2014:91) Manajemen Penjualan adalah perencanaan, pengarahan, dan pengawasan personal selling, termasuk penarikan, pemilihan, perlengkapan, penentuan rute, pengawasan, pembayaran, dan motivasi sebagai tugas yang diberikan kepada para tenaga kerja.

Tujuan kegiatan penjualan untuk sebuah perusahaan, pada umumnya mempunyai tiga tujuan umum penjualan, yaitu:

1) Mencapai volume penjualan tertentu;

2) Mendapatkan laba tertentu;

3) Menunjang pertumbuhan perusahaan.

Menurut (Iswi Hariyani, 2010:110) Usaha Mikro Kecil dan Menengah dapat diartikan sebagai berikut:

a. Usaha Jasa Skala Mikro

Usaha debitur UKM saat ini telah disempurnakan berdasarkan ketentuan pasal 1 dan pasal 6 UU 20/2008 tentang usaha mikro kecil dan menengah (UMKM). Definisi usaha mikro sesuai UU No.20/2008 adalah usaha produktif milik orang perorangan dan /atau badan usaha perorangan yang memenuhi kriteria:

1) Memiliki kekayaan bersih paling banyak Rp. 50 juta tidak termasuk tanah dan bangunan tempat usaha; atau 
2) Memiliki hasil penjualan tahunan paling banyak Rp. 300 juta.

b. Usaha Jasa Skala Kecil

Usaha kecil, sesuai pasal 1 dan pasal 6 UU 20/2008 adalah usaha ekonomi produktif yang berdiri sendiri, yang dilakukan oleh orang perorangan atau badan usaha yang bukan merupakan anak perusahaan atau bukan cabang perusahaan yang dimiliki, dikuasai, atau menjadi bagian baik secara langsung maupun tidak langsung dari usaha menengah atau usaha besar yang memenuhi kriteria:

1) Memiliki kekayaan bersih lebih dari Rp. 50 juta hingga Rp. 500 juta tidak termasuk tanah dan bangunan tempat usaha; atau

2) Memiliki hasil penjualan tahunan lebih dari Rp. 300 juta hingga Rp. 2,5 miliar.

c. Usaha Jasa Skala Menengah Usaha menengah, sesuai pasal 1 dan pasal 6 UU 20/2008, adalah usaha ekonomi produktif yang berdiri sendiri, yang dilakukan oleh orang perorangan atau badan usaha yang bukan merupakan anak perusahaan atau cabang perusahaan yang dimiliki, dikuasai, atau menjadi bagian baik langsung maupun tidak langsung dengan usaha kecil atau besar, dan yang memiliki kriteria sebagai berikut:

1) Memiliki kekayaan bersih lebih dari Rp. 500 juta hingga Rp. 10 miliar tidak termasuk tanah bangunan dan tempat usaha; atau

2) Memiliki hasil penjualan tahunan lebih dari Rp. 2,5 miliar hingga Rp. 5 miliar.

\section{METODE PENELITIAN}

Desain penelitian ini menggunakan metode kuantitatif dengan tujuan untuk mengukur efektivitas analisa faktor-faktor yang mempengaruhi pemilihan lokasi terhadap tingkat penjualan pada usaha jasa skala mikro dan kecil di desa Blimbing-Paciran-Lamongan. Subjek yang diteliti adalah pemilik usaha jasa yang ada di sekitar desa blimbing..

Teknik pengambilan sampel terdiri atas populasi dan sampel. Populasi menurut (Sugiyono, 2012:80) dapat didefinisikan sebagai wilayah generalisasi yang terdiri dari obyek atau subyek yang mempunyai kualitas dan karakteristik tertentu yang ditetapkan oleh peneliti untuk dipelajari dan kemudian ditarik kesimpulannya. Jadi populasi dari penelitian ini adalah semua usaha jasa berskala mikro-kecil yang berada di Desa Blimbing-Paciran-Lamongan yang berjumlah 64 usaha jasa. Sedangkan Sampel menurut (Sugiyono, 2012:81), adalah bagian dari jumlah karakteristik yang dimiliki oleh populasi tersebut. Dan yang digunakan sebagai sampel berjumlah 35 usaha jasa.

Menurut (Sugiyono, 2012:137146) teknik pengumpulan data kuantitatif terdiri atas:

a. Observasi digunakan bila
penelitian berkenaan dengan
perilaku manusia, proses kerja,
gejala-gejala alam dan bila
responden yang diamati tidak
berlalu besar atau banyak;


b. Wawancara digunakan sebagai teknik pengumpulan data apabila peneliti ingin melakukan studi pendahuluan untuk menemukan permasalahan yang harus diteliti, dan juga apabila peneliti ingin mengetahui hal-hal dari responden yang lebih mendalam dan jumlah respondennya sedikit;

c. Angket atau kuesioner adalah teknik pengumpulan data yang dilakukan dengan cara memberi seperangkat pertanyaan atau pernyataan tertulis kepada responden untuk di jawab. Angket cocok digunakan untuk responden dalam jumlah besar.

Alat yang digunakan untuk mengambil data dari pengusahapengusaha tersebut adalah kuesioner.

Dalam penelitian ini, variabel yang digunakan adalah:

1). Variabel Independent/Variabel bebas adalah variabel yang mempengaruhi atau yang menjadi sebab perubahannya atau timbulnya variabel dependen (terikat).

Variabel bebas dalam keseluruhan judul adalah "Pemilihan Lokasi" dalam penelitian ini pemilihan lokasi dijabarkan menjadi tiga variabel, yaitu: infrastruktur (X1), lingkungan bisnis (X2), biaya lokasi (X3).

2). Variabel dependen/Variabel terikat merupakan variabel yang dipengaruhi atau yang menjadi akibat karena adanya variabel bebas.
Variabel terikat dalam penelitian ini adalah "tingkat penjualan", sebagai variabel yang dipengaruhi.

\section{Metode Analisis Data}

Menurut (Sugiyono, 2012:150), analisis data adalah proses mencari dan menyusun secara sistematis data yang diperoleh dari hasil wawancara, catatan lapangan, dan dokumentasi, dengan cara mengorganisasikan data ke dalam kategori, menjabarkan ke unit-unit, melakukan sintesa, menyusun ke dalam pola, memilih mana yang penting dan yang akan dipelajari, dan membuat kesimpulan sehingga mudah difahami oleh diri sendiri maupun orang lain.

Dalam hal ini penulis harus memeriksa dan menguji ada tidaknya hubungan metode ini dengan cara:

1) Uji Validitas dan Uji Reliabilitas;

2) Analisis Regresi Berganda;

3) Uji Asumsi Klasik, yang terdiri atas uji normalitas, uji multikolinearitas, uji heterokedastisitas;

4) Koefisien Determinasi;

5) Goodness Of Fit, yang terdiri atas uji t dan uji F.

Perhitungan ini menggunakan statistik SPSS Versi 20.

\section{HASIL PENELITIAN DAN PEMBAHASAN}

Dengan menggunakan kriteria tiga kotak (Three-box Method), maka rentang sebesar 0,3 akan digunakan sebagai dasar interpretasi nilai indeks sebagai berikut : 
$0,1-0,40=$ Tidak Setuju $0,41-0,70$

$=$ Netral $0,71-1,0=$ Setuju

Tabel 1.

Tanggapan Responden Infrastruktur

\begin{tabular}{|c|c|c|c|c|c|c|}
\hline $\begin{array}{c}\text { Indikat } \\
\text { or }\end{array}$ & \multicolumn{5}{|c|}{$\begin{array}{c}\text { Frekuensi Jawaban Responden Mengenai } \\
\text { Kedekatan Dengan Infrastruktur }\end{array}$} & \multirow{2}{*}{$\begin{array}{c}\text { Indek } \\
\text { s } \\
\text { Kede } \\
\text { katan } \\
\text { Deng } \\
\text { an } \\
\text { Infras } \\
\text { truktu } \\
\text { r }\end{array}$} \\
\hline $\begin{array}{c}\text { atan } \\
\text { Denga } \\
\mathrm{n} \\
\text { Infrast } \\
\text { ruktur }\end{array}$ & 1 & 2 & 3 & 4 & 5 & \\
\hline $\begin{array}{l}\text { Keters } \\
\text { ediaan } \\
\text { Listrik }\end{array}$ & $0 / 35$ & $0 / 35$ & $5 / 35$ & $20 / 35$ & $10 / 35$ & 0,824 \\
\hline $\begin{array}{l}\text { Keters } \\
\text { ediaan } \\
\text { Air } \\
\text { Bersih } \\
\end{array}$ & $0 / 35$ & $0 / 35$ & $8 / 35$ & $12 / 35$ & $15 / 35$ & 0,838 \\
\hline $\begin{array}{l}\text { Adany } \\
\text { a } \\
\text { Akses } \\
\text { Jalan } \\
\text { Berasp } \\
\text { al }\end{array}$ & $0 / 35$ & $0 / 35$ & $15 / 35$ & $15 / 35$ & $5 / 35$ & 0,74 \\
\hline $\begin{array}{l}\text { Keters } \\
\text { ediaan } \\
\text { Lahan } \\
\text { Parkir }\end{array}$ & $0 / 35$ & $0 / 35$ & $6 / 35$ & $14 / 35$ & $15 / 35$ & 0,85 \\
\hline $\begin{array}{l}\text { Tingka } \\
\mathrm{t} \\
\text { Keama } \\
\text { nan }\end{array}$ & $0 / 35$ & $0 / 35$ & $8 / 35$ & $12 / 35$ & $15 / 35$ & 0,838 \\
\hline & & & tal & & & 0,818 \\
\hline
\end{tabular}

Sumber: Pendapatan data responden di Kabupaten Lamongan 2015

Angka indeks di atas diperoleh dari perhitungan sebagai berikut :

a. Indeks Ketersediaan Listrik

$=((1 \mathrm{x}(0 / 35))+(2 \mathrm{x}(0 / 35))+(3 \mathrm{x}(5 / 35)$

)$+(4 x(20 / 35))+(5 x(10 / 35))) / 5=$ 0,824

b. Indeks Ketersediaan Air Bersih

$=((1 \mathrm{x}(0 / 35))+(2 \mathrm{x}(0 / 35))+(3 \mathrm{x}(8 / 35)$

)$+(4 x(12 / 35))+(5 \times(15 / 35))) / 5=$

0,838

c. Indeks Adanya Akses Jalan

Beraspal Di Depan Lokasi Usaha

$=((1 \times 0 / 35))+(2 \times(0 / 35))+(3 \times(15 / 35)$

)$+(4 \times(15 / 35))+(5 \times(5 / 35))) / 5=0,74$

d. Indeks Ketersediaan Lahan Parkir

$=((1 \mathrm{x}(0 / 35))+(2 \mathrm{x}(0 / 35))+(3 \mathrm{x}(6 / 35)$

)$+(4 \times 14 / 35))+(5 \times(15 / 35))) / 5=0,85$ e. Indeks Tingkat Keamanan

$=((1 \mathrm{x}(0 / 35))+(2 \mathrm{x}(0 / 35))+(3 \mathrm{x}(8 / 35)$

)$+(4 \times(12 / 35))+(5 \times(15 / 35))) / 5=$

0,838

Indeks kedekatan dengan infrastruktur: $0,824+0,838+0,74+$ $0,85+0,838=0,818$.

Berdasarkan tabel 1 di atas kriteria kelima indikator tersebut termasuk setuju.

Tabel 2.

Tanggapan Responden Lingkungan

Bisnis

\begin{tabular}{|c|c|c|c|c|c|c|}
\hline \multirow{2}{*}{$\begin{array}{c}\text { Indikato } \\
\mathrm{r} \\
\text { Kedeka } \\
\text { tan } \\
\text { Dengan } \\
\text { Lingku } \\
\text { ngan } \\
\text { Bisnis }\end{array}$} & \multicolumn{5}{|c|}{$\begin{array}{l}\text { Frekuensi Jawaban Responden Mengenai } \\
\text { Kedekatan Dengan Lingkungan Bisnis }\end{array}$} & \multirow{2}{*}{$\begin{array}{c}\text { Indeks } \\
\text { Kedeka } \\
\tan \\
\text { Dengan } \\
\text { Lingku } \\
\text { ngan } \\
\text { Bisnis }\end{array}$} \\
\hline & 1 & 2 & 3 & 4 & 5 & \\
\hline $\begin{array}{l}\text { Kedeka } \\
\text { tan } \\
\text { dengan } \\
\text { Bisnis } \\
\text { Jasa } \\
\text { Lain } \\
\end{array}$ & $0 / 35$ & $0 / 35$ & $10 / 35$ & $13 / 35$ & $12 / 35$ & 0,808 \\
\hline $\begin{array}{l}\text { Kedekat } \\
\text { an } \\
\text { dengan } \\
\text { Konsu } \\
\text { men }\end{array}$ & $0 / 35$ & $0 / 35$ & $5 / 35$ & $10 / 35$ & $20 / 35$ & 0,882 \\
\hline $\begin{array}{l}\text { Kedekat } \\
\text { an } \\
\text { dengan } \\
\text { Pesaing }\end{array}$ & $2 / 35$ & $3 / 35$ & $14 / 35$ & $16 / 35$ & $0 / 35$ & 0,648 \\
\hline $\begin{array}{l}\text { Kedekat } \\
\text { an } \\
\text { dengan } \\
\text { Suplier }\end{array}$ & $0 / 35$ & $0 / 35$ & $0 / 35$ & $15 / 35$ & $20 / 35$ & 0,912 \\
\hline $\begin{array}{l}\text { Keleng } \\
\text { kapan } \\
\text { Peralata } \\
\mathrm{n}\end{array}$ & $0 / 35$ & $0 / 35$ & $0 / 35$ & $12 / 35$ & $23 / 35$ & 0,93 \\
\hline & & & & & & 0,836 \\
\hline
\end{tabular}

Sumber: Pendapatan data responden

di Kabupaten Lamongan 2015

Angka indeks di atas diperoleh dari perhitungan sebagai berikut :

a. Indeks Kedekatan dengan Bisnis Jasa Lain:

$$
\begin{aligned}
& =((1 \mathrm{x}(0 / 35)+(2 \mathrm{x}(0 / 35)+(3 \mathrm{x}(10 / 35) \\
& +(4 \mathrm{x}(13 / 35)+(5 \mathrm{x}(12 / 35))) / 5=0,808
\end{aligned}
$$


b. Indeks Kedekatan dengan Konsumen :

$=((1 \mathrm{x}(0 / 35)+(2 \mathrm{x}(0 / 35)+(3 \mathrm{x}(5 / 35)+($ $4 \mathrm{x}(10 / 35)+(5 \mathrm{x}(20 / 35))) / 5=0,882$

c. Indeks Kedekatan dengan Pesaing

$$
\begin{aligned}
& =((1 \times(2 / 35)+(2 \times(3 / 35)+(3 \times(14 / 35) \\
& +(4 \times(16 / 35)+(5 \times(0 / 35))) / 5=0,648
\end{aligned}
$$

d. Indeks Kedekatan dengan Suplier :

$$
=((1 \mathrm{x}(0 / 35)+(2 \mathrm{x}(0 / 35)+(3 \mathrm{x}(0 / 35)+(
$$$$
4 \mathrm{x}(15 / 35)+(5 \mathrm{x}(20 / 35))) / 5=0,912
$$

e. Indeks Kelengkapan Peralatan:

$$
=((1 \mathrm{x}(0 / 35)+(2 \mathrm{x}(0 / 35)+(3 \mathrm{x}(0 / 35)+(
$$$$
4 \mathrm{x}(12 / 35)+(5 \mathrm{x}(23 / 35))) / 5=0,93
$$

Indeks lingkungan bisnis $=0,808+$ $0,882+0,648+0,912+0,93=0,836$.

Berdasarkan tabel 2 di atas ada satu indikator yang memiliki kriteria netral yaitu 0,648 dengan indikator kedekatan dengan pesaing. Sedangkan indikator lainnya memiliki kriteria setuju.

\section{Tabel 3.}

Tanggapan Responden Biaya Lokasi

\begin{tabular}{|c|c|c|c|c|c|c|}
\hline \multirow{2}{*}{$\begin{array}{c}\text { Indikator } \\
\text { Kedekatan } \\
\text { Dengan } \\
\text { Biaya } \\
\text { Lokasi }\end{array}$} & \multicolumn{4}{|c|}{$\begin{array}{c}\text { Frekuensi Jawaban Responden } \\
\text { Mengenai Kedekatan Dengan }\end{array}$} & $\begin{array}{c}\text { Indeks } \\
\text { Kedekat } \\
\text { an } \\
\text { Dengan } \\
\text { Biaya } \\
\text { Lokasi }\end{array}$ \\
\cline { 2 - 5 } & 1 & 2 & 3 & 4 & 5 & 0,796 \\
\hline $\begin{array}{c}\text { Harga Sewa } \\
\text { Tempat } \\
\text { Usaha }\end{array}$ & $0 / 35$ & $5 / 35$ & $0 / 35$ & $20 / 35$ & $10 / 35$ & 0,824 \\
\hline $\begin{array}{c}\text { Ada/Tidakn } \\
\text { ya Biaya } \\
\text { Renovasi }\end{array}$ & $0 / 35$ & $0 / 35$ & $5 / 35$ & $20 / 35$ & $10 / 35$ & 0,638 \\
\hline $\begin{array}{c}\text { Ada/Tidakn } \\
\text { ya Insentif } \\
\text { Bangunan }\end{array}$ & $0 / 35$ & $13 / 35$ & $7 / 35$ & $10 / 35$ & $5 / 35$ & 0,648 \\
\hline $\begin{array}{c}\text { Besarnya } \\
\text { Pajak }\end{array}$ & $2 / 35$ & $3 / 35$ & $14 / 35$ & $16 / 35$ & $0 / 35$ & 0,638 \\
\hline $\begin{array}{c}\text { Tingkat } \\
\text { Suku Bunga }\end{array}$ & $0 / 35$ & $13 / 35$ & $7 / 35$ & $10 / 35$ & $5 / 35$ & 0,7088 \\
\hline \multicolumn{7}{|c|}{ Total } \\
\hline
\end{tabular}

Sumber: Pendapatan data responden di Kabupaten Lamongan 2015

Angka indeks di atas diperoleh dari perhitungan sebagai berikut : a. Indeks Harga Sewa Tempat Usaha:

$=((1 \mathrm{x}(0 / 35))+(2 \mathrm{x}(5 / 35))+(3 \mathrm{x}(0 / 35$ )$)+(4 x(20 / 35))+(5 x(10 / 35))) / 5=0$, 796

b. Indeks Ada Tidaknya Biaya Renovasi: $=((1 \mathrm{x}(0 / 35))+(2 \mathrm{x}(0 / 35))+(3 \mathrm{x}(5 / 35$ )$)+(4 x(20 / 35))+(5 x(10 / 35))) / 5=$ 0,824

c. Indeks Ada/ Tidaknya Insentif Bangunan: $=((1 \times(0 / 35))+(2 \times(13 / 35))+(3 \times(7 / 3$ $5))+(4 \times(10 / 35))+(5 \times(5 / 35))) / 5=$ 0,638

d. Indeks Besarnya Pajak: $=((1 \times(2 / 35))+(2 x(3 / 35))+(3 x(14 / 3$ $5))+(4 \times(16 / 35))+(5 \times(0 / 35))) / 5=$ 0,648

e. Indeks Tingkat Suku Bunga $=((1 \mathrm{x}(0 / 35))+(2 \mathrm{x}(13 / 35))+(3 \mathrm{x}(7 / 3$ $5))+(4 \times(10 / 35))+(5 \times(5 / 35))) / 5=$ 0,638

Indeks biaya lokasi : $0,796+$ $0,824+0,638+0,648+0,638$ $=0,7088$.

Berdasarkan tabel 3 di atas hanya dua indikator yang termasuk setuju yaitu indikator harga sewa tempat dan ada/tidaknya biaya renovasi, sedangkan yang lain netral.

\begin{tabular}{|c|c|c|c|c|c|c|}
\hline \multirow{2}{*}{$\begin{array}{l}\text { Indikator } \\
\text { Tingkat } \\
\text { Penjualan }\end{array}$} & \multicolumn{5}{|c|}{$\begin{array}{c}\text { Frekuensi Jawaban Responden } \\
\text { Mengenai Tingkat Penjualan }\end{array}$} & \multirow{2}{*}{$\begin{array}{c}\text { Indeks } \\
\text { Kedekat } \\
\text { an } \\
\text { Dengan } \\
\text { Tingkat } \\
\text { Penjual } \\
\text { an } \\
\end{array}$} \\
\hline & 1 & 2 & 3 & 4 & 5 & \\
\hline $\begin{array}{c}\text { Tingkat } \\
\text { Kedatang } \\
\text { an } \\
\text { Pelangga }\end{array}$ & $0 / 35$ & $0 / 35$ & $5 / 35$ & $0 / 35$ & $0 / 35$ & 0,824 \\
\hline
\end{tabular}

Tabel 4.

Tanggapan Responden Tingkat Penjualan 


\begin{tabular}{|c|c|c|c|c|c|c|}
\hline $\mathrm{n} /$ hari & & & & & \\
\hline $\begin{array}{c}\text { Pertumbu } \\
\text { han Laba } \\
\text { Bersih }\end{array}$ & $0 / 35$ & $0 / 35$ & $8 / 35$ & $9 / 35$ & $8 / 35$ & 0,854 \\
\hline $\begin{array}{c}\text { Waktu } \\
\text { Tercapain } \\
\text { ya BEP }\end{array}$ & $0 / 35$ & $0 / 35$ & $4 / 35$ & $5 / 35$ & $6 / 35$ & 0,694 \\
\hline $\begin{array}{c}\text { Rol } \\
\text { Usaha }\end{array}$ & $0 / 35$ & $0 / 35$ & $0 / 35$ & $9 / 35$ & $6 / 35$ & 0,658 \\
\hline $\begin{array}{c}\text { Pencapaia } \\
\text { n Real } \\
\text { Profit } \\
\text { Usaha }\end{array}$ & $0 / 35$ & $7 / 35$ & $0 / 35$ & $0 / 35$ & $8 / 35$ & 0,706 \\
\hline \multicolumn{7}{|c|}{ Total } \\
\hline
\end{tabular}

Sumber : Pendapatan data responden di Kabupaten Lamongan 2015

Angka indeks di atas diperoleh dari perhitungan sebagai berikut :

a. Indeks Tingkat Kedatangan Pelanggan/Hari:

$=((1 \mathrm{x}(0 / 35))+(2 \mathrm{x}(0 / 35))+(3 \mathrm{x}(5 / 35$

)$)+(4 x(20 / 35))+(5 x(10 / 35))) / 5=$

0,824

b. Indeks Pertumbuhan Laba Bersih:

$=((1 \mathrm{x}(0 / 35))+(2 \mathrm{x}(0 / 35))+(3 \mathrm{x}(8 / 35$

)$)+(4 \times(9 / 35))+(5 \times(18 / 35))) / 5=$ 0,854

c. Indeks Waktu Tercapaian BEP: $=((1 \mathrm{x}(0 / 35))+(2 \mathrm{x}(10 / 35))+(3 \mathrm{x}(4 / 3$ $5))+(4 \times(15 / 35))+(5 x(6 / 35))) / 5=$ 0,694

d. Indeks Rol Usaha:

$=((1 \mathrm{x}(0 / 35))+(2 \mathrm{x}(10 / 35))+(3 \mathrm{x}(10 /$ $35))+(4 \times(9 / 35))+(5 x(6 / 35))) / 5=$ 0,658

e. Indeks Real Profit Usaha $=((1 \times(0 / 35))+(2 \times(7 / 35))+(3 \times(10 / 3$

$5))+(4 \times(10 / 35))+(5 x(8 / 35))) / 5=$

0,706

Indeks tingkat penjualan: $0,824+$ $0,854+0,694+0,658+0,706=$ 0,7472 .

Berdasarkan tabel 4 di atas ada dua indikator yang memiliki kriteria netral yaitu indikator waktu tercapainya BEP dan rol usaha. Sedangkan yang lain termasuk setuju.

\section{Analisa Data}

\section{Uji Validitas dan Uji Reliabilitas}

a. Uji Validitas

Dari hasil uji validitas diperoleh nilai untuk variabel X1 (infrastruktur) yaitu nilai X1.1 sebesar 0,727, nilai X1.2 sebesar 0,396, nilai X1.3 sebesar 0,694, nilai X1.4 sebesar 0,587 , dan nilai X1.5 sebesar 0,727. Untuk variabel X2 (lingkungan Bisnis) yaitu nilai X2.1 sebesar 0,679 , nilai X2.2 sebesar 0,578, nilai X2.3 sebesar 0,818 , nilai X2.4 sebesar 0,368 , dan nilai X2.5 sebesar 0,640 . Untuk variabel X3 (Biaya Lokasi) yaitu nilai X3.1 sebesar 0,730, nilai X3.2 sebesar 0,395 , nilai X3.3 sebesar 0,830 , nilai X3.4 sebesar 0,513, dan nilai X3.5 sebesar 0,830. Untuk variabel $\mathrm{Y}$ (Tingkat Penjualan) yaitu nilai Y1.1 sebesar 0,820 , nilai Y1.2 sebesar 0,916, nilai Y1.3 sebesar 0,866, nilai Y1.4 sebesar 0,946, dan nilai Y 1.5 sebesar 0,853 .

Dengan demikian dapat disimpulkan bahwa indikator variabel infrastruktur (X1), Lingkungan Bisnis (X2), Biaya Lokasi (X3), dan Tingkat Penjualan (Y) dinyatakan valid karena nilai $r$ hitung $\geq \mathrm{r}$ tabel sebesar 0,344. Sehingga seluruh indikator yang ada pada variabel-variabel penelitian tersebut layak untuk digunakan. 
b. Uji Reliabilitas

Dari masing-masing variabel diperoleh nilai Cronbach Alpha yaitu untuk variabel infrastruktur (X1) sebesar 0,614, untuk variabel lingkungan bisnis (X2) sebesar 0,615 , untuk variabel biaya lokasi (X3) sebesar 0,684, untuk nilai tingkat penjualan (Y) sebesar 0,928 .

Dengan demikian dapat disimpulkan bahwa semua variabel dikatakan reliabel karena memiliki nilai Cronbach Alpha $\geq$ 0,6. Sehingga seluruh variabel yang ada pada indikator variabel penelitian ini dikatakan layak untuk digunakan.

\section{Uji Asumsi Klasik}

a. Uji Normalitas

Dari grafik histogram dan gambar PPlot terlihat titik-titik mengikuti dan mendekati garis diagonalnya sehingga dapat disimpulkan bahwa model regresi memenuhi asumsi normalitas.

b. Uji Multikolinearitas

Dari masing-masing variabel diperoleh nilai VIF untuk nilai variabel infrastruktur (X1) sebesar 1,177, untuk nilai variabel lingkungan bisnis (X2) sebesar 1,292, dan nilai variabel biaya lokasi (X3) sebesar 1,298. Dapat disimpulkan bahwa semua variabel tidak mengalami multikolinearitas karena nilai VIF lebih kecil dari 10.

c. Uji Heteroskedastisitas

Berdasarkan hasil output SPSS didapatkan titik-titik menyebar di atas dan di bawah sumbu Y, dan tidak mempunyai pola yang teratur, jadi kesimpulannya variabel bebas tidak terjadi heteroskedastisitas.

\section{Analisis Regresi Berganda}

Dari uji regresi linier berganda menghasilkan persamaan:

$\mathrm{Y}=-10,323+0,318 \mathrm{X} 1+0,701 \mathrm{X} 2+$ 0,443 X3

Dari persamaan regresi linier berganda tersebut di atas, maka dapat diartikan bahwa:

a) $\mathrm{a}=-10,323$

Menunjukkan bahwa jika semua variabel bebas tidak mengalami perubahan atau konstan, maka tingkat penjualan naik sebesar -10,323.

b) b1 $=0,318$

Jika terjadi kenaikan sebesar satu satuan pada variabel infrastruktur (X1), sedangkan variabel lingkungan bisnis (X2) dan biaya lokasi (X3) konstan, maka tingkat penjualan naik sebesar 0,318 .

c) b2 $=0,701$

Jika terjadi kenaikan sebesar satu satuan pada variabel lingkungan bisnis (X2), sedangkan variabel infrastruktur (X1) dan biaya lokasi (X3) konstan, maka tingkat penjualan naik sebesar 0,701 .

d) b3 $=0,443$

Jika terjadi kenaikan sebesar satu satuan pada variabel biaya lokasi (X3), sedangkan variabel infrastruktur (X1) dan lingkungan bisnis (X2) 
konstan, maka tingkat penjualan naik sebesar 0,443.

\section{Koefisien Determinasi}

Dari hasil pengolahan data SPSS diperoleh besarnya Adjusted R2 adalah 0,269. Hal ini berarti bahwa $26,9 \%$ variasi tingkat penjualan dapat dijelaskan oleh variasi dari ketiga variabel independen yakni Kedekatan dengan Infrastruktur, Lingkungan Bisnis, dan Biaya Lokasi, sedangkan $73,1 \%$ lainnya dijelaskan oleh sebabsebab lain diluar model.

Uji Goodness Of Fit

\section{a. Uji t}

Dari uji t diperoleh hasil sebagai berikut:

1) t hitung $\mathrm{X} 1 \quad 1,067 \leq \mathrm{t}$ tabel 1,695 sehingga $\mathrm{Ha}$ di tolak dan $\mathrm{Ho}$ diterima artinya tidak ada pengaruh yang signifikan antara kedekatan dengan infrastruktur terhadap tingkat penjualan. Sehingga hipotesis yang menyatakan bahwa kedekatan dengan infrastruktur berpengaruh secara signifikan ditolak.

2) t hitung $\mathrm{X} 2 \quad 2,200 \leq \mathrm{t}$ tabel 1,695 sehingga $\mathrm{Ha}$ di terima dan $\mathrm{Ho}$ ditolak artinya ada pengaruh yang signifikan antara kedekatan dengan lingkungan bisnis terhadap tingkat penjualan. Sehingga hipotesis yang menyatakan bahwa kedekatan dengan infrastruktur berpengaruh secara signifikan diterima.

3) t hitung $X 32,064 \leq t$ tabel 1,695 sehingga $\mathrm{Ha}$ di terima dan $\mathrm{Ho}$ ditolak artinya ada pengaruh yang signifikan antara kedekatan dengan biaya lokasi terhadap tingkat penjualan. Sehingga hipotesis yang menyatakan bahwa kedekatan dengan infrastruktur berpengaruh secara signifikan diterima.

b. Uji F

Dari hasil uji ANOVA didapat uji Fhitung 5,170 $\geq 2,91$ dan signifikan 0,005 $<0,05$ maka tolak Ho terima $\mathrm{Ha}$ yang artinya terdapat pengaruh yang signifikan antara variabel kedekatan dengan infrastruktur, lingkungan bisnis dan biaya lokasi terhadap tingkat penjualan

Berdasarkan uraian di atas diketahui bahwa tidak ada pengaruh yang signifikan antara kedekatan dengan infrastruktur dan biaya lokasi terhadap tingkat penjualan jasa mikro kecil di sekitar Desa Blimbing Kecamatan Paciran Kabupaten Lamongan. Dan ada pengaruh yang signifikan antara lingkungan bisnis terhadap tingkat penjualan. Besarnya pengaruh dari ketiga variabel bebas $\mathrm{X} 1, \mathrm{X} 2$, dan $\mathrm{X} 3$ terhadap tingkat penjualan (Y) adalah 0,269 atau 26,9\%. Hal ini menunjukkan bahwa kedekatan dengan infrastruktur tidak memberikan andil yang cukup besar terhadap tingkat penjualan sedangkan lingkungan bisnis dan biaya lokasi sangat besar andilnya terhadap tingkat penjualan mikro kecil di Desa Blimbing Kecamatan Paciran Kabupaten Lamongan. Sedangkan sisanya $73,1 \%$ dipengaruhi oleh faktor lain. 


\section{KESIMPULAN DAN SARAN Kesimpulan}

Penelitian ini mencoba untuk meneliti, apakah Kedekatan dengan Infrastruktur, Lingkungan Bisnis, dan Biaya Lokasi mempengaruhi pemilihan lokasi terhadap tingkat penjualan jasa mikro kecil di Desa Blimbing Kecamatan Paciran Kabupaten Lamongan. Dengan memperhatikan hasil analisis dan pembahasan yang dilakukan sebelumnya, maka dapat ditarik beberapa kesimpulan penelitian sebagai berikut :

1. Tidak ada pengaruh secara parsial untuk variabel infrastruktur (X1) dengan dari perhitungan regresi 0,318. Ada pengaruh secara parsial antara variabel lingkungan bisnis dan variabel biaya lokasi pada Desa Blimbing Kecamatan Paciran Kabupaten Lamongan. Variabel lingkungan bisnis (X2) mempengaruhi pemilihan lokasi terhadap tingkat penjualan (Y) dari perhitungan regresi 0,701 sedangkan variabel biaya lokasi (X3) mempengaruhi pemilihan lokasi terhadap tingkat penjualan (Y) dari perhitungan regresi 0,443 . Untuk Uji t variabel infrastruktur (X1) diperoleh thitung 1,067 $\leq$ ttabel 1,695 sehingga Ha ditolak dan Ho diterima, untuk Uji $t$ variabel lingkungan bisnis (X2) diperoleh thitung 2,200 $\leq$ ttabel 1,695 sehingga Ha di terima dan Ho ditolak, dan untuk variabel biaya lokasi (X3) diperoleh thitung $2,064 \leq$ tabel 1,695 sehingga $\mathrm{Ha}$ di terima dan $\mathrm{Ho}$ ditolak.

2. Ada pengaruh secara simultan antara variabel kedekatan dengan infrastruktur (X1), lingkungan bisnis (X2), dan biaya lokasi (X3) terhadap tingkat penjualan (Y) dari perhitungan Uji $\mathrm{F}$ diperoleh nilai sebesar Fhitung 5,170 $\geq$ Ftabel 2,91 maka Ha diterima dan Ho ditolak.

3. Dari ketiga variabel independen yang diajukan dalam penelitian ini, variabel lingkungan bisnis adalah variabel yang memiliki pengaruh yang paling dominan terhadap variabel dependen yakni tingkat penjualan jasa mikro kecil yang berada di Desa Blimbing Kecamatan Paciran Kabupaten Lamongan.

\section{Saran}

Adapun saran penulis bagi pemilik usaha jasa mikro kecil di desa blimbing kecamatan paciran kabupaten lamongan adalah sebelum mendirikan usaha jasa pemilik harus memperhatikan faktor-faktor pemilihan lokasi dengan baik karena faktor-faktor tersebut sangat mempengaruhi jalannya usaha agar dapat menghasilkan tingkat penjualan yang diharapakan. Sehingga perusahaan juga dapat bersaing dengan perusahaan lain yang bergerak di bidang yang sama dan dapat menambah daya tarik konsumen untuk menggunakan usaha jasa agar dapat meningkatkan pendapatan bagi perusahaan. 


\section{DAFTAR PUSTAKA}

Haming, M. dan Nurnajamuddin, M. (2014). Manajemen Produksi Modern Operasi Manufaktur dan Jasa. Jakarta: PT. Bumi Aksara

Hariyani, Iswi. (2010). Restrukturisasi \& Penghapusan Kredit Macet. Jakarta: PT. Elex Media Komputindo Kompas Gramedia

Herlambang, Susatyo. (2014). Basic Marketing (Dasar-Dasar Pemasaran) Cara Mudah Memahami Ilmu Pemasaran. Yogyakarta: Gosyen Publishing.

Rusdiana. (2014). Manajemen Operasi. Bandung: CV. Pustaka Setia.

Santoso, Singgih. (2014). Panduan Lengkap SPSS Versi 20 Edisi Revisi. Jakarta: PT. Elex Media Komputindo.

Sugiyono. (2012). Metode Penelitian Kuantitatif Kualitatif dan $R \&$ $D$. Bandung: Alfabeta.

Suliyanto. (2010). Studi Kelayakan Bisnis Pendekatan Praktis. Yogyakarta: C.V Andi Offset.

Tim Dosen Metodologi Penelitian. (2015). Pedoman Penulisan Skripsi. Lamongan: Pusat Penelitian UNISLA. 